\title{
Corruption and Entrepreneurship in Kenya
}

\author{
Irene Ngunjiri
}

\begin{abstract}
Africa has many bridges that dot the landscape with no roads to lead to them. This is because many projects are started but never get completed due to corruption. The bridge is completed but government often run out of funds to build the road. Corruption has become a common phenomenon in many developing and emerging economies. There are different views on the effects of corruption on entrepreneurship. What is clear is that entrepreneurship is paramount for economic growth. Entrepreneurship development is driven by a number of factors principally social, psychological and economic. All these factors are subject to corruption and consequently can deter entrepreneurship. This paper examines the impact of corruption on entrepreneurship in Kenya. The findings indicate that when formal institutions are inefficient corruption which subverts these institutions is beneficial in terms of economic development. Conversely, where formal institutions are relatively efficient, corruption is detrimental.
\end{abstract}

Key words: corruption, business, entrepreneurship, Kenya, economy

\subsection{Introduction}

Corruption was the buzz word for the National Rainbow Coalition (Narc), the winning party, during the 2002 election campaign in Kenya. John Githongo ${ }^{1}$, a political analyst and former journalist, described corruption in Kenya as being systemic, endemic. It pervades all the levels of the nation (2003). Kenya has been fraught with a number of scandals among them Goldenberg, Anglo leasing, Maize, oil, Grand/ Laico Regency among others. Kenya remains in the bottom 20 percent of Transparency International's Corruption Perception Index (CPI) ${ }^{2}$ The fact that it persists there, at least in terms of perception, makes Kenya appear one of the world's most corrupt countries. Kenya has had a number of commissions set up to unravel the scandals but all of them have proved to be an exercise in futility ${ }^{3}$ A survey done in 2004 by the World Bank and the Kenya Institute for Public Policy Research shows that graft still oils the wheels of business in Kenya. Half of the firms surveyed said that they had been asked for a bribe in the past year.

\footnotetext{
${ }^{1}$ Former Permanent secretary in charge of Ethics and Governance 2003

${ }^{2}$ Transparency international

${ }^{3}$ Exodus news 2006
} 
In (1996) the World Bank rated Kenya as the 17th poorest nation in the world However, it fares fairly well when compared to its immediate neighbors although according to the 2008 CPI it is perceived to be most corrupt in Eastern Africa. Kenya, the regional hub for trade and finance in East Africa, is hampered by corruption and reliance on several primary goods whose prices remain low. ${ }^{4}$ Kenya's economy has stagnated with GDP growth failing to keep up with the rate of population growth. In 1997, the IMF suspended Kenya's Enhanced Structural Adjustment Program due to the government's failure to maintain reforms and curb corruption.

One of the primary determinants of growth is entrepreneurship, the ability of a nation's citizens, and of foreign investors, to engage in building new businesses, or in restructuring existing establishments in order to adjust to changes in the economic and political environment. Economic growth is aided by entrepreneurship. Entrepreneurship, in turn, may be facilitated by economic growth (Wilkin 1979, 25). This symbiotic relationship makes separating cause and effect difficult. Nevertheless, economists from Schumpeter to Rostow have argued that the innovational part of entrepreneurship is crucial for economic development and growth. It is entrepreneurship that leads to higher productivity, the ability to produce more from the same amount of work: economic growth (Palifka, 2006).

Corruption drastically affects economic development by causing a misallocation of resources. What is damaging to an economy is the fact that in endemically corrupt systems, regular people are not getting served by the government and as they don't trust the government they don't interact with the government. As these people have to get things done, they create their own systems to do things, such as resolve disputes or enforce contacts or get ways to circumvent the rules and laws. Economic development depends on change. The agent of change is the individual entrepreneur responding to the incentives embodied in the institutional framework.Corruption is an informal institution that influences entrepreneurship (Mbaku, 1996).

\subsection{Entrepreneurship}

There seems to be no agreement on the definition of entrepreneurship. Chell et al (1991) state that the problem of identification of the entrepreneur has been confounded by the fact that there is still no standard universally accepted definition of entrepreneurship. Often the term entrepreneurship is equated to new venture creation and small business management Gibb (1999). Baumol (1987) points out that most neo- classical economists recognize that there three primary economic factors of production: raw materials, labor and capital. These components have to be brought together by individuals. Some economists regard entrepreneurship as a kind of fourth factor which acts on the other three to combine them in productive ways (Kirby, 2003).

Entrepreneurs operate within both economic and societal contexts. Not only do they make the economic system more competitive but they drive changes in the structure of society.

\footnotetext{
${ }^{4}$ Kenya Entrepreneurial, 1996
} 
Wickham (1998) has proposed that there is a hierarchy of entrepreneurial activities operating in different social areas. At the core or base is what is conventionally known as entrepreneurship namely the profit making business venture; at the next level there is the management of the not for profit organizations such as charities and public sector institutions, above this is the social and cultural activities, while at the top are activities aimed at creating wholesale social change such as political activity Kirby, (2003). Entrepreneurship involves not only the process that leads to the setting up of a business entity but also the expansion and development of an ongoing concern.

Entrepreneurship is a vast subject as it does not alone correspond to a single academic discipline, but relates to numerous disciplines such as economics, sociology, demography, and psychology. Hence, it is a multifaceted and a multidisciplinary subject with complex social, cultural, and economic phenomena. But it requires creativity and innovation that are consistent with the healthy edge required to change the basis of competition. Entrepreneurship is at the top of the cultural, economic, and political agenda. It is considered as one of the main keys for unlocking economic growth, and as a result the policymakers worldwide have attempted to implement certain strategies that cherish and sustain entrepreneurial activity Michel J Lynskey, (2002).

\subsubsection{Factors Contributing to Entrepreneurship}

Entrepreneurship is studied as a process of creating new firms (Gartner, 1988; and Krueger and Brazeal, 1994). It involves exceptional kinds of decision-making process. The success of every venture depends on the entrepreneur's personality structure and on many other influences such as internal and external factors. If entrepreneurship is important for growth-that is, if entrepreneurship is an activity to be promoted - then it is necessary to identify ways to encourage entrepreneurship. Palifka, (2006) divided these into three groups: psychological factors, social factors, and economic factors. Each of these factors will be defined and areas that are vulnerable to corruption identified. Corruption is the abuse of public office for private gain.

\subsubsection{Psychological factors.}

These consist primarily of individual characteristics, determined genetically or in the home and they allow little scope for policy. Ehigie et al (2003) found out that self-concept, perceived managerial competence, work stress and business commitment as important psychological variables for perceived entrepreneurial success among female entrepreneurs in Nigeria. Everett Hagen (1962) introduced the notion of innovative personality as the prerequisite for economic growth, spread of entrepreneurship and capital formation. The main psychological requirement is an innovational personality for an individual with imagination is less risk-averse, and is more likely to undertake investment projects. (Leff $1979,47)$ Although it might be argued that such a personality is determined exogenously by the parents' genes, it may also be true that creativity can be encouraged in the school or work environment. Specific skills common to entrepreneurs include: the ability to set 
realistic goals and defer gratification, a willingness to take risks, and possession of an internal locus of control.

\subsubsection{Social factors.}

The supply of entrepreneurs may be affected by a number of social factors, including social mobility, the degree of social integration, entrepreneurial and political security ("protection from unnecessary risks", e.g., the enforcement of patent laws), and the social/cultural legitimacy of entrepreneurial activity. The marginalization of some groups, especially the exclusion of educated groups from the political process, has been identified by Rostow (1975) and others as contributing to entrepreneurship, but excessive marginalization can be detrimental. (Wilkin, 8-14) A country's institutions may influence these social factors and policy can shape these institutions. Several of the social factors are vulnerable to corruption. Social mobility, for example, will be stunted especially by traditional forms of corruption such as nepotism: only those with close family connections will be able to move up. The enforcement of patent and other laws is an area that offers opportunities for corruption.

\subsubsection{Economic factors.}

Market incentives determine the demand for entrepreneurs. This demand will interact with the supply of entrepreneurs to arrive at the level of entrepreneurship in a given country or region. The most important incentives are the demand for industrial and other products, the availability of labor and raw inputs, the level of inflation, taxes, and barriers to the imports of necessary inputs. All of these may be affected by public policy; all may be subject to corruption. Further determinants of the demand for entrepreneurs are the cost of attaining information about markets, the distribution of income, and access to resources. These are especially important in relation to corruption. High information costs and limited access to resources may increase the potential gains from corruption, which subsequently limits access to resources and preserves the disparate distribution of income in a vicious, self-perpetuating circle.

\subsection{Corruption}

The World Bank defines corruption as the misuse of public power for private gain is and is difficult to measure directly because of secretive, dishonest nature. Various indices are used, such as TI's Corruption Perceptions Index (CPI: a meta-survey) Global Competitiveness Report (GCR), International Country Risk Guide (ICRG), BEEPS, and Business International Index (BI). (Nye, 2002) states that corruption is behavior which deviates from the formal duties of a public role because of private-regarding (personal, close family, private clique) pecuniary or status gains; or violates rules against the exercise of certain types of private-regarding influence. This includes such behavior as bribery (use of 
a reward to pervert the judgment of a person in a position of trust); nepotism (bestowal of patronage by reason of ascriptive relationship rather than merit); and misappropriation (illegal appropriation of public resources for private-regarding uses) (Mbaku, 1996)

David Bayley (1966: 720) argues that corruption, while being tied particularly to the act of bribery, is a general term covering the misuse of authority as a result of considerations of personal gain, which need not be monetary. Herbert Werlin (1973: 73) defines political corruption as the "diversion of public resources to nonpublic purposes. In Africa many people see corruption as a practical problem involving the outright theft, embezzlement of funds or other appropriation of state property, nepotism and the granting of favors to personal acquaintances, and the abuse of public authority and position to exact payments and privileges" (Harsch 1993: 33) in (Mbaku, 1996).

Prof Philip M. Nichols (2002) argues that corruption threatens the global market place as it affects the decisions made by the political leaders, reduces the efficacy of those in power and discourages internal and foreign investments. He further states that corruption and bribery have moved to the forefront in discussions about business and the list of countries that have been politically or economically crippled by corruption continues to grow, and businesses with long-term interests abroad will ultimately be harmed by any plans that include bribery. African leaders must reject the view that as individuals we are linked only by commercial transactions, and that we are accountable to no one, and need to justify our actions to nobody.

Fraser Molekati, South Africa's ex- Minister of Public Service and Administration 1999 2008, asserts that business and political leaders must be convinced that economic development cannot be at all costs. We cannot develop by allowing a permissive environment for corruption to flourish. Corruption is detrimental to long term sustainable development. Corruption costs and grand corruptions costs even more. Corruption is inimical to development; it perpetuates inequality, increases wealth and asset gaps between rich and poor on national, regional, continental and global scales. It reproduces conditions of underdevelopment and poverty. It is morally wrong and offensive; it is illegal and it can no longer be tolerated

Many researchers have tried to explain the international discrepancies in corruption rates as being mainly due to the different formal institutional environment. Informal institutional aspects, such as culture bounded attitudes, norms, traditions and habits have been mostly neglected (Treisman, 2000). Corruption in developing countries is often believed to arise from the clash or conflict between traditional values and the imported norms that accompany modernization and socio-political development. Bureaucratic corruption is seen by some researchers, then, as an unavoidable outcome of modernization and development (Alam 1989, Bayley 1966) in Sarkar and Hasan ( 2001). 


\subsubsection{Types of corruption}

David Osterfeld (1992) has argued that in a heavily regulated economy, one can find two distinct types of corruption: "expansive corruption," which involves activities that improve the competitiveness and flexibility of the market; and "restrictive corruption," which limits opportunities for productive and socially beneficial exchange.

Restrictive corruption, Osterfeld (1992) argues, is characterized by redistribution of income and wealth in favor of individuals or groups. Most public-sector corruption falls in the restrictive category and involves illegal appropriation of public resources for private use (e. g. outright embezzlement by a civil servant) or the illegal use of an individual's public position for his own personal enrichment. Public-sector corruption hinders the proper functioning of the market system, retards economic growth, and thus is restrictive corruption. As examples of expansive corruption, Osterfeld (1992,) mentions the bribing of judges, politicians and bureaucrats by members of the private sector. The payment of bribes to the right officials, he argues, can help mitigate the harmful effects of excessive government regulation and improve economic participation (Mbaku, 1996).

Mullei (2003) classifies corruption into petty corruption, grand corruption and looting. Petty corruption involves relatively minor amounts of money or gifts changing hands where one of the parties is themselves a relatively minor official in the organisation or system within which the transaction takes place. For example, paying a policeman fifty shillings to ignore the fact that your car's licence has expired. Grand corruption most often involves businessmen and government officials of senior rank and the figures involved are significant. Examples of these are kick-backs paid to officials on government public works contracts. The third type of corruption is 'looting' and has recently been described by some commentators as large-scale economic delinquency. It differs slightly from petty and grand corruption, however, and is sadly prevalent in those Third World countries where institutions of governance are particularly weak. It usually involves the kind of scams whose figures are so huge that when they are successfully concluded they have macroeconomic implications fairly quickly - they cause banks to collapse, inflation to rise, the exchange rate to decline.

\subsection{Corruption and entrepreneurship}

For profit-maximizing enterprises faced with ruinous government regulations, bureaucratic corruption can be viewed as a survival mechanism. In African countries, payments from entrepreneurs seeking state favors represent an important source of extra-legal income for civil servants. A society's laws and institutions have a significant impact on the level of bureaucratic corruption. State regulatory programs can place a significant burden on business enterprises and entrepreneurship and encourage investors to seek ways to minimize these state-imposed costs. Most intervention schemes, create rents that are usually competed for through a political process. Paying bribes to civil servants has emerged as an important method to compete for those rents (Mbaku, 1992) and (Harsch, 1993). 
Although certain types of corruption may have beneficial economic and political effects, for example it may motivate tax officials, corruption can permit inefficient firms to remain in business indefinitely. Contrary to Osterfeld's (1992) claim, the firms offering the highest bribes are not necessarily the most economically efficient ones but the ones that are efficient at rent seeking. A study of the Yucatan, Margaret Goodman (1990: 642-43) found that corruption did not benefit efficient producers, but instead protected incompetent entrepreneurs. The firms that survived under institutionalized corruption were those that had become efficient at rent seeking, not at properly and effectively servicing their markets. The expertise that improved their ability to survive was their knowledge of the political process, who to bribe, and how to effectively manipulate the political system to their advantage. In addition, Goodman (1990) found that corruption in the Yucatan did not ensure new groups or entrepreneurs opportunities to enter the market. Instead, corruption allowed the old and more established groups to totally dominate and monopolize markets (Mbaku, 1996).

Gary Becker (1994: 18) remarked that corruption is common whenever big government infiltrates all facets of economic life, never mind the political and business systems. If the country's rules make the political system the primary determinant of firm profitability, then entrepreneurs are likely to devote most of their resources, including their time, to rent seeking. For example, if state subsidies, discretionary tax relief, and other forms of regulations instead of managerial expertise, business acumen, and competition become the primary determinants of the profitability of firms, rent seeking, including bureaucratic corruption, would become pervasive. Entrepreneurs in such an economy will devote a significant portion of their activities to lobbying and bribing politicians and civil servants in an effort to maximize profit levels (Mbaku, 1996).

Mauro finds "that corruption is strongly negatively associated with the investment rate, regardless of the amount of red tape", asserting further that "there is evidence that institutional inefficiency causes low investment." (Mauro 1995, 695) Everhart and Sumlinski (2001) find that public investment "crowds out" private investment and that in more corrupt countries, the crowding out effect is stronger. They argue that when government projects are tainted by corruption, the quality of infrastructure suffers and this discourages private investment. Taslim (1994) argues that corruption in the form of bribetaking is like sand in a machine rather than oil because it drives out firms with lower entrepreneurial skills from the market. Obviously, developing countries where entrepreneurial skills are in particular very scarce are adversely affected because there will be even fewer active entrepreneurs who can seek out profitable opportunities and directly add to the wealth of the nation in addition to enriching themselves.

Sarkar and Hasan, (2001) noted that the presence of corruption inflicts substantial economic costs on an economy. Corruption is a double edged sword; it reduces both the volume and efficiency of investment and thus economic growth. They concluded that substantial gains in terms of economic growth could be achieved if corruption is reduced. Malesky and Krislert Samphantharak (2008) found out that firms exposed to a shock to their bribe schedules by a change in governor invest significantly less in subsequent periods, as they wait for new information about their chief executive. Predictability in the 
amount that the firm is going to pay in bribes is critically important in individual firm investment decisions. The finding is robust to a battery of firm-level controls and provincelevel investment climate measures. Further they alluded to the fact that changes in governor are most strongly associated with changes in corruption predictability, not other measures of general stability in the business environment.

Corruption affects entrepreneurship in a myriad of ways. By limiting access to government funds and permits, the government agents reduce participation in some kinds of entrepreneurial activity to their own circle of friends and relatives, or to people who have access to this circle and can get a representative. In this respect, personal relations represent a kind of social capital (Bezerra 1994, 5) in scarce supply. Funds and contracts go not to the best proposals, but to those proposals which have sponsors within the agency in charge. At the same time, this corruption reduces the rewards for merit and reinforces the belief that the only roads to success are through luck or through corruption, and not through education. Thus the returns to education are perceived to be low, resulting in lower enrollment rates than would be observed in the absence of corruption. The waiving of technical audits, however, reduces government expenditures on gathering information, potentially leaving more funds for entrepreneurial projects. The risk is that the projects will not be technically or economically viable (Palifka, 2006).

Khan and Toufique (1995) argued that corruption does have positive effects on entrepreneurship. According to them can act as grease to the wheels of economic growth in the following ways: Bypasses government inefficiency (Red Tape Model); Might increase motivation of tax officials; Bribes may provide market mechanisms, but lack of legal transactional assurance and secret/uncompetitive nature of bribes reduces efficiency. Taslim also argued that corruption actually increased entrepreneurship since entrepreneurs have often sought out corrupt transactions as cost-reducing strategies.

Nathaniel Leff (1964) launched inquiry into the possibility that corruption may be a positive phenomenon under some circumstances. When formal institutions are inefficient (e.g., red tape that strangles investment), corruption which subverts these institutions is beneficial in terms of economic development. Conversely, where formal institutions are relatively efficient, corruption is detrimental. What we should bear in mind is that many developing countries are underdeveloped administratively as well as economically, and it is this administrative inefficiency which makes corruption socially optimal. Nevertheless, corruption with inefficient formal institutions is arguably worse than efficient formal institutions with no corruption (Palifka, 2006).

\subsection{Measuring the effects of corruption on entrepreneurship in Kenya}

TI-Kenya's has for the last seven years constructed the Kenya Bribery Index (KBI). The survey is part of its effort to inform the fight against corruption with rigorous and objective research and analysis. The survey captures as experienced by ordinary citizens in their interaction with officials of both public and private organizations. The respondents were asked to provide information on the organizations where they have encountered bribery 
during the past year, how much they paid, for what and their perception of corruption in the country.

\subsection{Corruption rankings of organizations}

On the Aggregate Index scale of 0-100 the respondents were asked to indicate how corrupt they perceived certain organizations to be. Table I gives the findings.

Table 1: Corruption rankings of organizations in Kenya in 2008

\begin{tabular}{|l|l|l|}
\hline Rank & Organization & Aggregate Index \\
\hline 1 & Kenya Police & 57 \\
\hline 2 & Other Local Authorities/Ministry of Local Government. & 47 \\
\hline 3 & Ministry of Lands & 37 \\
\hline 4 & Immigration Dept. & 36 \\
\hline 5 & Private Universities & 34 \\
\hline 6 & Provincial Administration & 33 \\
\hline 7 & Nairobi City Council & 31 \\
\hline
\end{tabular}

Source: KBI 2008

The Kenya Police, Local Authorities/the Ministry of Local Government and the Ministry of Lands have a high degree of continuity in the top rankings. The police have a greater capacity to extract a bribe. Generally failure to comply with a bribe demand by the police usually results in failure to access a certain service or avoid a penalty. In Kenya the police are perceived to be widely corrupt and people are often surprised when we encounter an honest policeman. It must also be noted that the high score by the police could also be due to the fact that the services that they provide are on high demand. Entrepreneurs will go to the police to report crimes or to have disputes resolved. Local authorities are responsible for collecting land rates and rent and issuing of trading licenses. Corruption in this sector could slow down the efforts of entrepreneurs to venture into new businesses.

\subsection{Total bribery payments}

The respondents were asked to indicate the total bribery payments in 2007 . Table 2 below shows the responses.

Table 2: Total bribery payments by respondents in 2008

\begin{tabular}{|l|l|l|}
\hline Amount Paid (KSh.) & Frequency & Percent of Sample \\
\hline 0 & 568 & 24 \\
\hline $1-200$ & 212 & 8 \\
\hline $201-500$ & 226 & 9 \\
\hline $501-1,000$ & 241 & 10 \\
\hline $1,001-2,000$ & 243 & 10 \\
\hline $2,001-5,000$ & 324 & 14 \\
\hline $5,001-10,000$ & 208 & 9 \\
\hline
\end{tabular}




\begin{tabular}{|l|l|l|}
\hline $10,001-20,000$ & 204 & 9 \\
\hline $20,000+$ & 174 & 7 \\
\hline TOTAL & $\mathbf{2 4 0 0}$ & 100 \\
\hline
\end{tabular}

Source: KBI 2008

The proportion of respondents who did/did not make bribery payments over the previous year: 76 and 24 percent, respectively as shown in table 2 above. The bribes paid by $50 \%$ of the respondents are above kshs. 1,000. Considering that more than half of the population in Kenya lives below the poverty line living below a dollar a day, this amount is quite high. ${ }^{5}$

\subsection{The purpose for the bribe and the Average size of the bribe}

The respondents were asked to state the purpose of paying bribes out of the following five: (1) to obtain some service ("service"), (2) to obtain some license or permit and thus comply with some law or regulation ("regulatory compliance"), (3) to avoid a fine or some other punitive measure ("law enforcement"), (4) to facilitate a contract or commercial transaction ("business"), and (5) to obtain employment ("employment"). Table 3 and Fig I below show the responses.

Table 3: Number of Transactions (Percent of Total) vs. the purpose for the bribe payment in 2008

\begin{tabular}{|l|l|l|l|}
\hline Year & $\mathbf{2 0 0 8}$ & $\mathbf{2 0 0 7}$ & $\mathbf{2 0 0 6}$ \\
\hline Service & 45 & 29 & 26 \\
\hline Regulatory Compliance & 19 & 24 & 20 \\
\hline Law Enforcement & 24 & 36 & 46 \\
\hline Business & 6 & 7 & 4 \\
\hline Employment & 6 & 4 & 3 \\
\hline
\end{tabular}

Source: KBI 2008

Fig 1: Showing the Average size of Bribes Paid

${ }^{5}$ Index Mundi, 2008 


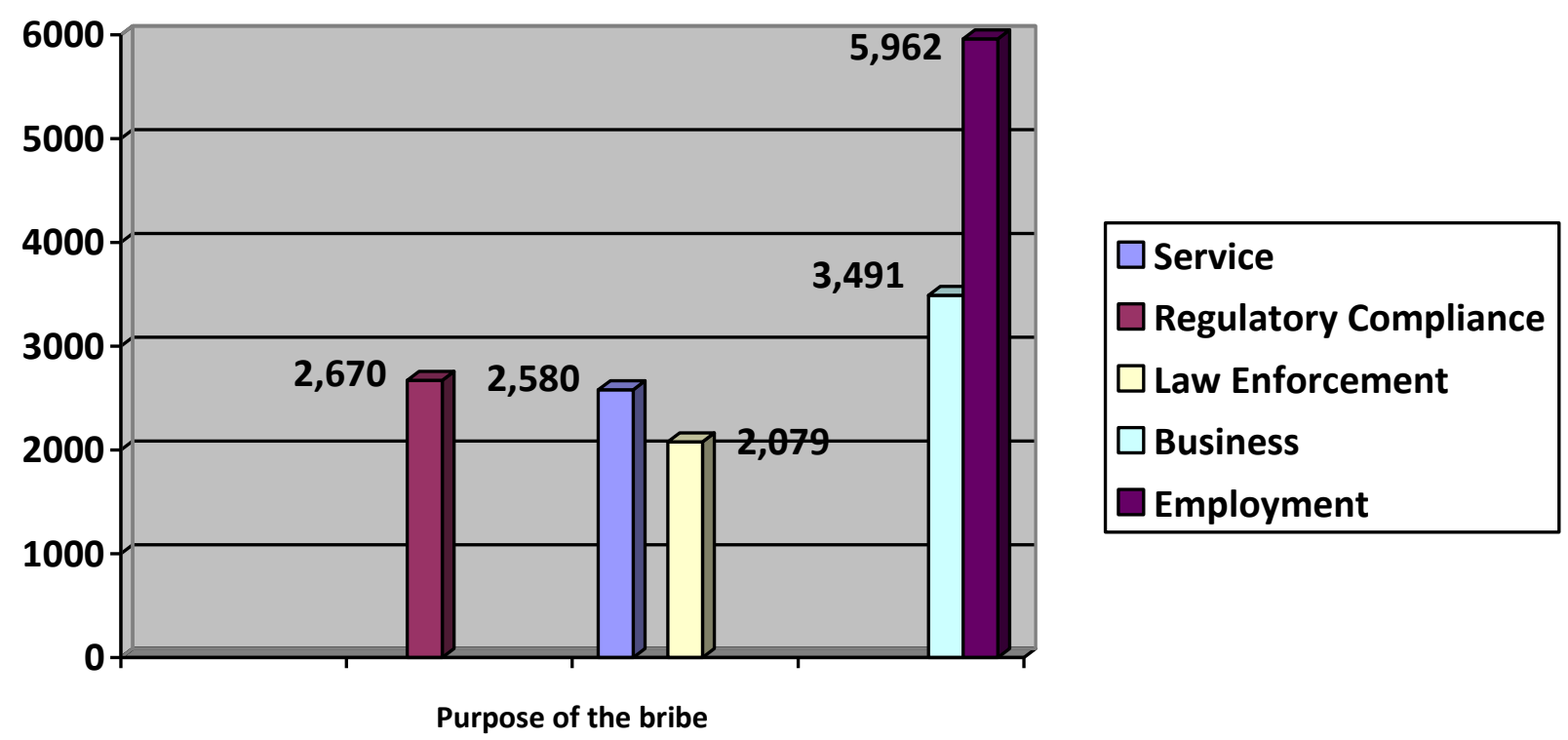

Source: KBI 2008

From table 3 and Fig I above it clear that a typical entrepreneur will have to pay bribes to obtain services from government offices, to obtain licenses to start their business, to avoid fines and to facilitate contracts or commercial transaction. Effectively he may have to pay kshs, 10,280 on average to get the business going. Corruption in this area may create barriers to entry for small enterprises.

\subsection{Corruption perceptions}

The survey also captured general perceptions of corruption in the country. Table 4 presents the findings as compared to those in the previous three KBIs. It emerges that there was little change. The only notable movement was towards the negative, with a total perception of this nature (i.e., "a lot worse" + "a little worse") increasing from 13, 18, 20, 18 over the last four years, respectively, to 27 percent currently.

Table 4: Changes In Perceptions of Corruption: 2008 Vs. Previous (Percent)

\begin{tabular}{|l|l|l|l|l|l|}
\hline Perceived Change & 2008 & 2007 & 2006 & 2005 & 2004 \\
\hline A little better & 22 & 20 & 15 & 15 & 18 \\
\hline
\end{tabular}




\begin{tabular}{|l|l|l|l|l|l|}
\hline A lot better & 13 & 15 & 11 & 10 & 14 \\
\hline A little worse & 10 & 7 & 7 & 6 & 4 \\
\hline A lot worse & 17 & 11 & 13 & 12 & 9 \\
\hline No change & 37 & 47 & 55 & 56 & 55 \\
\hline
\end{tabular}

Source: KBI 2008

Kenyans seem to see the probability of encountering a bribe to be increasing over the years. With time there seems to be a shift in the government's focus from combating corruption to politics. Investors would shy away from a country where there is one has to bribe so as to get the requisite conditions for starting or operating a business.

\subsection{Conclusion}

It is clear the entrepreneurs may be spending some of their time and energy in unproductive and destructive entrepreneurship looking for ways to influence government officials. Entrepreneurs have to be creative in devising mechanisms to get around corrupt systems. Corruption undermines policies designed to encourage entrepreneurship. There is no way to determine the precise effect that corruption has on entrepreneurship. What is clear from the Corruption Perception index by Transparency International is that countries that rank high on the list are high rates of economic growth.

Corruption prevents economic growth because it distorts incentives and market signals leading to misallocation of resources. Moreover, corruption in Kenya, where it has degenerative impact, destroys the productive capacity of local talent and entrepreneurs. The opportunities for corrupt practices lead to resources, especially human resources, being channeled into rent seeking rather than productive activities Entrepreneurial and academic skills may be attracted to public sectors to earn extra benefit through corruption. Entrepreneurs may also find it financially more rewarding to leave the private sector and instead become a corrupt public official. As a result, growth of private sector may be reduced.

Kenya is currently trying to put its act together so as to institute reforms in a number of sectors of the economy. These reforms may aid in the removal of long standing traditions of corruption. One thing that is clear is that for this to happen there has to be political will and a paradigm shift among Kenyans. We need to believe that we can conduct business in all sectors without the intervention of corruption mechanisms and that it is possible to deinstitutionalize corruption. Long term measures to be taken that aim at fundamentally changing the formal institutions. Short term measures such as corruption campaigns serve to reduce corruption only when they are in effect. 


\section{References}

Africa Policy E-Journal January 21, 2003 (030121); Kenya: Anti-Corruption on the Agenda; University of Pennsylvania African studies Center; http://allAfrica.com

Axel Dreher and Martin Gassebner (2007) "Greasing the Wheels of Entrepreneurship? Impact of Regulations and Corruption on Firm Entry" KOF Working Paper No. 166; CESifo Working Paper No. 2013, http://www.icgg.org/downloads/contribution11 tonoyan.pdf.

Bjornskov, Ch. and Paldam, M. (2002): "Corruption Trends and Social Capital", Paper submitted to the International Workshop on Corruption at the University of Goettingen, November, http://www.asb.dk/eok/nat/staff

Ehigie, et al 2003, "Psychological factors influencing perceived entrepreneurial success among Nigerian women in small-scale businesses" Journal of International Women's Studies Publication Vol. 5 No. 1, 2003

Everhart, Stephen S. and Mariusz A. Sumlinski. 2001. Trends in Private Investment in Developing Countries: Statistics for 1970-2000 and the Impact on Private Investment of Corruption and the Quality of Public Investment. International Finance Corporation Discussion Paper 44, World Bank

Harch, E. (1993) "Accumulators and Democrats: Challenging State Corruption in Africa." Journal of Modern African Studies 31(1): 31-48.

Hiren Sarkar and M Aynul Hasan, (2001); Impact of corruption on the efficiency of investment: evidence from cross country analysis Asia-Pacific Development Journal Vol. 8, No. 2, December 2001

http://knowledge.wharton.upenn.edu/article.cfm?articleid=646) How bribery and other types of Corruption Threaten the Global Marketplace: Knowledge @Wharton October 23, 2002

http://www:tikenya.org/documents/KenyaBriberyIndex08.pdf

Kirby. D (2003), Entrepreneurship, 1 ${ }^{\text {st }}$ edition, Mc Graw Hill

Malesky and Krislert Samphantharak (2008); "Predictable corruption and Firm investment: Evidence from a Natural Experiment and Survey of Cambodian Entrepreneurs" Quarterly Journal of Political Science, 2008, 3: 227-267

Mauro. P (1995), "Corruption Country Risk and Growth", Quarterly Journal of Economics, Vol. 110, No. 4, pp. 681-712.

Mbaku John (1996), "Bureaucratic Corruption in Africa: The Futility of Cleanups" Cato Journal, Vol. 16, No. 1 (Spring/Summer 1996). 
Michel J Lynskey and Seiichiro Yonekura, (2002), Entrepreneurship and Organization, $1^{\text {st }}$ Edition, Amazon Publishers

Mullei Andrew, (2003); Linkages between corruption and poverty: Lessons from Kenya: Case Studies; International Centre for Economic Growth

Palifka Bonnie (2006), Corruption and entrepreneurship in Brazil, paper presented at the 150-mile conference Edinburg, Texas April 22, 2006

Taslim M (1994), "Corruption and Entrepreneurship", The Bangladesh Development Studies, Vol. 22, No. 1, pp. 117-32.

Treisman, Daniel (2000): "The Causes of Corruption: A Cross-National Study", Journal of Public Economics 76, 3, June 2000, pp.399-457.

www.transparency.org; Corruption Perception Index 2008 